\title{
THE ROLE OF THE NUBIAN WOMAN, THE BEARER OF HERITAGE, IN PRESERVING THE CULTURAL IDENTITY
}

Nevin Mohamed KHALIL *

Department of Popular Formation Arts and Material Culture, Higher Institute for Folk Art, Academy of Arts, Egypt

\begin{abstract}
The Egyptian civilization passed through many cultures, through which it made a strong civilization that brought together the ancient Egyptian, Byzantine, Coptic and Islamic civilizations, until Egypt had a long history, and the history of Nubia was not separated from the civilizations that Egypt experienced, which greatly affected the role and effectiveness of Nubian women in society and with She preserves the authentic qualities of Egyptian women, the most important of which are loyalty, chastity, stamina, and strength of patience. Nubian women played an important role in Nubian society; As it is the cornerstone and backbone of the Nubian house, it is responsible for caring for children, directing the land and agriculture, in addition to its responsibilities towards the home and its service. These many responsibilities have earned the Nubian women experience, experience, maturity and awareness of life affairs.

Keywords

The Nubian Woman, The Bearer Of Heritage, Preserving, The Cultural Identity.
\end{abstract}

\section{Introduction}

Nubian women were distinguished by their privacy in all their affairs, as they were distinguished in their uniforms, cells, and wedding rituals. They also excelled in crafts and handicrafts, as well as reflected their ancient culture in the way they decorate the walls of their home. This research will address several axes that review the role of the Nubian woman who loves beauty in everything. We present it as follows: - The diversity of the natural environment and geographical conditions of the Nuba had an important role in the formation of the Nubian woman's personality. Depositing the Nubian woman in decorating and decorating the walls of homes .. Fashion and accessories .. Jewelry .. Her role in preserving the Nubian language.

-The role of Nubian women in society and the preservation of popular culture, through the study of handicrafts and traditional crafts flourishing in Nubia, such as handicrafts, beads and dishes made of wicker. The role of civil and women's associations in developing Nubian women and preserving cultural identity.

\section{The Aim of the Research :}

- Standing on the role of Nubian women towards meeting the needs of the Nubian community, the environment and industries related to traditional crafts. Shedding light on the artistic creations of Nubian women.

- Shedding light on Nubian women's civil institutions, and their role in marketing the products of Nubian women, and enhancing communication between generations by

* Corresponding author: media@moc.gov.eg 
transferring expertise and training a new generation capable of competing in the Egyptian and international market.

- Shedding light on the role of elderly Nubian women in transferring experiences.

First: The impact of the environment on the formation of the personality of the Nubian woman-:

Nubia - humans and its location - occupied a distinctive place in the life of Egypt and the Egyptians in the past and present, as it includes an Egyptian human group with special social and cultural features, and as it represents the site of the southern gate of the Arab Republic of Egypt.

There is no doubt that the migrations that Nubia underwent - four migrations - had the greatest impact on some changes in Nubian society. Especially in the formation of the Nubian woman's personality and arts, and the traditional crafts that distinguished them from their counterparts of traditional crafts on the map of Egypt. These continuous migrations have caused a change in the nature of the environment and changed the map of Nubian villages, as well as a deep gap between the generation carrying the preserved heritage and the generations that followed it. Nubian women are the biggest burden in introducing the new generation to the ancient heritage of its ancestors.

There is no doubt that the huge heritage of Nubian art owes thanks to the Nubian woman, for whom geographical, environmental and societal factors provided the suitable soil for the explosion of her creative energy, as these factors made her closely related to the cultural traditions inherited from the environment in which she lives, as her ideas are a harmonious fabric of her beliefs, customs and values of her society And the method of drawing the symbols by which they express all this is subject to recognized traditional lines, which were composed by society, and on which they established their standards through which they formed their artistic and aesthetic contents, and perhaps all this is what made the creativity of Nubian women characterized by the diversity and richness of decorations and colors that depend on the diversity of materials. As well as the multiplicity of methods of performance by which it carried out its works, especially the wicker works and the colorful wall decorative elements in architecture

\section{Characteristics of the Nubian woman:}

Nubian women are distinguished by their striking natural beauty and pure skin. She is a beautyloving woman who inherited her beauty and methods of preserving it from her old grandmothers. She used many tools in decorating her, starting with the "Qadmus", the Nubian Makhliya. It is a small copper vessel in which loose kohl is placed in it, and Nubian women 
use it to decorate and beautify the eyes, and also use it to decorate the newborn, either to beautify it or to protect it from envy. The lower lip of the mouth rang the "shelofa", which is a distinctive aesthetic feature, and was decorated by placing the reins on the nose.

She also made sure to appear in all social events, with the most beautiful and decorated; She was distinguished by her personal cleanliness and good distinctive smell, so she used multiple fragrances and fragrances, including musk oils, oud and sandalwood, and there are what are placed on the body such as "Nubian Dilqah Girl" which is a group of essential oils "and then they take a warm bath and the fragrance remains on the body for several days, as well. The "khamrah" (the Nubian fragrance) that is made for the bride before the wedding was used and it is one of the necessary customs and traditions. And the types of wine are the wine of the nail, and there is the Nubian incense on top of which is "sandalwood" and it is called the acacia wood, and the "khamrah" consists of the original sandalwood planted in India is extracted from the sandalwood tree and the nail, which is the crust of a type of fish in the Red Sea, and the Turkish musk which is stone musk, mahlab and nutmeg. And the types of liquid scents for Nubian women are "Ferira Damura, Country Door, Paris Bracelet, the two birds, the sandalwood smell, the Cologne scent." Bouquet, Sudan girl, Megoma and other scents" .

The Nubian woman is also distinguished by the strength of will, perseverance and skin, she is a social woman by nature keen to fully perform her social role within her small local community, but we see her often bypassing this small entity to fly in the global sky through her social role inside and outside her country eager to ensure the success Her case and her support for the Nubian man with all strength and firmness, for she is the one who established the rules for the exchange of benefits within her community, such as (furniture, food tools, and jewelry). In every village and village, we find affordable homes that the rest of the families resort to in order to fulfill their need for those purposes and return them after the end of the social event in all honesty, after spending One of the most important of these customs is the exchange of gold jewelry on occasions of marriage and engagement, and one of the established customs until now was to borrow any amount of gold jewelry from relatives or neighbors, and return it again after the end of the marriage ceremony.

In view of the great importance of the Nubian woman to her family, society and country, the 22nd of September was chosen to celebrate the Day of the Nubian Woman, due to the connection of this month in the ancient Egyptian calendar with the god Hathor, the ancient Egyptian goddess who played the role of mother and wife, shepherd and protector. 


\section{Marital Status of Nubian Women:}

A married woman knows the golden triangle (the story of the Most Gracious) hanging on her forehead (Picture 2). As for the girl, she leaves a strand of hair (plaster) on her forehead, this is evidence that she is a girl of the age of marriage, but the single woman or widow leaves her forehead bare. Except for a round ring of gold to be attached to (the story of the Most Merciful) if she gets married.

Older women also teach girls to make tools necessary for the home such as (wicker plates, bushes, brooms and baskets), raise livestock and sell them when necessary, deal with merchants outside the home to meet the needs of the family necessary to provide the household supplies throughout the year, and pay the dues on them from the date crop in The season of the tribe, as well as the burden of undertaking the distribution of shares in the seasons of cereal crops and dates, as this process is subject to certain rituals and prayers that precede the distribution that only elderly Nuba women know. The role of the Nubian woman does not stop at that point, but she alternates with her husband in agricultural work, as she takes over the management of the waterwheel so that her husband takes a rest, in which he takes lunch and a cup of tea so that he can complete his work in the field.

\section{Engagement and Marriage Ceremonies for Nubian Women:}

A large woman from the village, called the "wedding caller" or the time bearer, roams the streets of the village, piercing through its hamlets, calling for toned calls, carrying in her left hand a wicker plate decorated on top of a round wooden box, bright red and shaped like the domes of the mosques they call it.

In Nubia it is called "yes" and people are glad to see this woman when she sees her, so she is a professional advocate for weddings and happy occasions. This lady blows the ululation and the women respond to her, as the villagers pass by in a large procession of children and boys joining the procession "zaffa" by knocking on pieces of tin and tambourines for the children, and by the passage of this lady and the procession, the people of the village all consider themselves invited to participate in the joy and those who are left behind. He is to blame.

The people of the village gather, men, women and children, and slaughter sacrifices in both houses, "the bride and groom", and everyone spends the whole day working, singing and joy. The celebration of the henna night begins from the day before the day of joy and the wedding by a week or more, where everyone works as a beehive in preparing the two homes for the day of joy. Young men bring wood chunks, cut them and roast them for cooking purposes, and some climb the walls of the two houses to fix the affairs of the leaves, and they participate with girls and women in repairing the walls and decorating them with appropriate drawings. Corn 
and prepare it for grinding to become accurate to make the necessary bread on the day of joy, and they are busy making an abundant amount of "popcorn" and preparing bread discs that they then dry into small pieces of "abrih", which is a type of bread made from the fermented dough for the fattah, which is provided to the people The village after it was watered with soup and put in the story on the day of joy

\section{Results:}

The research extracted a set of results, including the following:

1- The Nubian society is a matrilineal society where the mother enjoys a great deal of power and sovereignty in the family, deriving from her high position descended from the past because most of the men traveled from the village to work abroad, so the burden of raising children and taking care of household and field affairs was placed on the woman.

2- The Nubian woman is responsible for all the work of the house since its inception, in order and decorating the facades of the houses with exquisite decorations and drawings derived from the inspiration of the environment.

3- The Nubian woman has mastered crafts and traditional industries, she excelled in decorating her rooms with what she creates by making her own hands of products derived from the inspiration of the environment from the colorful rugs and wicker dishes and decorated with geometric and symbolic elements that represent a practical background for the thought of the Nubian woman, and she stores these products in the "Al Diwan wing" "She takes from him her daughters' supplies when she moves to her husband's house.

4- Old women play a big role in transferring experiences to new generations, as they train young girls to make tools necessary for the home, such as (wicker plates, rugs, brooms, baskets, beadwork, and corsets.

5- The costumes of Nubian women have dignity and meaning, where young women wear the "drawer" and the elderly women "the commune", and the genius of the Nubian woman is evident in the design of the "drawer," so we see her decorating the middle area with nine pockets in anticipation of the pregnancy period. The fracture so that the front of the cress does not rise and exposes its legs.

6- The genius of the Nubian woman in using symbolic language without speaking in meeting the affairs of her daily life, as she created a special language for herself in her community, we mention it, for example, in the case of childbirth. A little girl is sent with a "knife" weapon to the midwife, and this is an indication that the woman is in a 
state of childbirth.

7- Nubian women took the lead in the idea of establishing nurseries, as the environmental conditions in this society imposed the absence of the mother from her children for long periods of time to fetch water from the Nile or fodder for livestock from the fields or to perform a social duty. Elderly women in the deaf or grandmothers take care of all the children of the pea - under two or three and even the infants of them - by distracting them with toys and stories until their mothers return.

8- Nubian women are the main entity around which all the various social events and activities revolve in the event of death or marriage. During wedding occasions they contribute with grains, dates, sugar and tea, and reception tables are prepared for guests, and women of different age groups participate in the preparation and implementation, and men have no role but slaughter Sacrifices and participation in singing and dancing nights.

9- The Nubian woman has established the most important customs in society, including the exchange of benefits (bedding, food utensils, and golden jewelry at weddings). In all well-off homes, the rest of the families resort to them to fulfill their needs from those purposes and return them honestly after relieving their needs.

10- Nubian women are the ones who distribute shares in the season of cereal and date crops, as this process is subject to certain rituals and prayers that precede the distribution process that only elderly women know. combine.

11- The ability of Nubian women to participate positively in the development movement depends on the rights and freedoms they enjoy, and the opportunities and capabilities available to them that enable them to play their role in reform and development.

\section{References}

1- Ashraf Owais: Egyptian jewelry, a treasure of the wealthy and simple adornments, Journal of Popular Culture, Folk Culture Archive for Studies, Research and Publishing, Bahrain, 6, 2009 AD.

2- Saad El-Khadem: Folk Arts in Nubia, The Cultural Library, Misr Library, Cairo 1966 AD.

3- Saleh Abdel-Moneim, Othman Al-Amir: Nubian Women ... Al-Ajyal School, Nubian Club Association for the Diffusion of Culture, State Information Service Press 2014 AD.

4- Adel Moussa, Mohi El-Din Saleh: - Nubian Days on the journey of Professor Anna Hohenfart, Bibliotheca Alexandrina, Center for Documentation of Cultural and Natural Heritage, Egyptian General Book Authority 2012.

5- Ali Zain Al-Abidin: The Art of Crafting Folk Nubian Jewelry, The General Egyptian Book 
Authority, 1981 AD.

6- Amr Abdel-Qader Mahmoud: Arts of Nubia, "a tradition, heritage and civilization."

7- Farid Fadel: The Search for Nubia, sponsored by CIB, 2010.

8- Mohieddin Sharif: Nubia, Stories and Memories, Dar Al-Uloom for Printing, 1986 AD.

9- Mohy Abdel-Hay: Folk Dance in Nubia, An Anthropological Study of the Art of Kinetic Performance, Folk Culture Series, Egyptian General Book Authority, 2016.

10- Nahid Baba: Nubian motifs in architecture and wicker dishes, Baladna Art Series, 1st Edition, Public Authority Palaces Culture, Al-Amal Company for Printing and Publishing 2008 AD.

11- Ahmed Shehata Abu Al-Majd: Studies in the colorful wall decorative elements in Nubian folk art and making use of them in modern formations, an unpublished master's thesis, Faculty of Applied Arts, Helwan University 1982.

12- Shawqi Abd Al-Marouf Abdel-Hafez: The Arts of the Nubia Region and Benefiting From It in Designing Tourist Ceramic Products "Souvenirs", an unpublished master's thesis, College of Applied Arts, Helwan University, 1982.

13- Jehan Farouk ABU AL-KHAIR, THE CONTEXTUAL CRITIQUE OF THE AESTHETICS OF FATIMID "WATER JUG COLANDER" AS AN INPUT TO ENRICH THE AESTHETIC EXPERIENCE OF ART EDUCATION'S STUDENTS, International Journal of Multidisciplinary Studies in Heritage Research, Vol. 2, No. 2, 2019, pp. 32-38.

Received: February 16, 2020

Accepted: April 17, 2020 